\title{
Productivity Dynamics: A Case of Pakistan
}

\author{
Muhammad Nadeem Javaid ${ }^{\text {a }}$, Gulzar Ahmed ${ }^{\text {b }}$ \\ ${ }^{a}$ Karachi School of Business and Leadership, National Stadium Road, 7480o Bahadurabad, Karachi, \\ Pakistan \\ Email: nadeemjavaid75@gmail.com \\ ${ }^{\mathrm{b}}$ Ministry of Planning Development \& Reform, Pakistan \\ Email: gulzar_maitla@yahoo.com
}

\begin{tabular}{ll}
\hline ARTICLE DETAILS & ABSTRACT \\
\hline History: & This study estimates the total factor productivity (TFP) for Pakistan at \\
Accepted 30 April 2021 & aggregate and sectoral level from 1982 to 2016 with a data set rebased \\
Available Online June 2021 & at 2005-06. We employ actual returns to scale instead of the \\
& oversimplified assumption of constant returns to scale for measuring the \\
& TFP. Our results show that average economic growth during this period \\
Keywords: & is 4.7 percent with o.7 percent contribution from TFP. While, average \\
Productivity, Aggregate and & TFP growth for Agriculture, Industry, and Services sector is 1.5, 4.6, and \\
Sectoral Level, Human Capital & 4.3 percent, respectively. Besides, there is a noticeable decreasing trend \\
Formation & in TFP as well as economic growth relative to 1980's. Further, our \\
& analysis reveals that the physical and human capital contribution in \\
JEL Classification: & productivity is quite negligible at aggregate and sectoral level. This \\
D24, O47 & implies that size able investments in human capital formation can \\
& further help the economy to attain high growth trajectory in the short to \\
& medium terms.
\end{tabular}

(C) 2021 The authors. Published by SPCRD Global Publishing. This is an open access article under the Creative Commons Attribution-

NonCommercial 4.0

Corresponding author's email address: nadeemjavaid75@gmail.com

\section{Introduction}

Economic growth of a country is fuelled by rising labour productivity and total factor productivity; which is a portion of output driven by operational efficiency, managerial skills, innovation, and competitiveness. Measurement and interpretation of the productivity is a major interest of entrepreneurs and policy-makers to untangle the complex factors of economy (Nadiri, 1970). Regardless of data and methodologies, TFP is widely accepted as a driver to create the difference in world's income as compared to saving rates, labour and the capital stock that makes a relatively small difference (Prescott, 1998; Hall and Jones, 1999; Jerzmanowski, 2007 and Comin, 2006). However, some studies show that major contribution in output growth is due to factor inputs; Jorgenson and Griliches (1967) found that 96.7 percent growth in output is inputs driven and the rest is explained by TFP. Solow (1956) used the technology as an exogenous variable and suggested that technology and the capital accumulation account for major increase in the output per worker. The endogenous growth theories used the technology as an endogenous variable and argued that output growth mainly 
Review of Economics and Development Studies, Vol. 7 (2) 2021, 187-203

determined by knowledge spill-over, innovation and human capital (Romer, 1990; Grossman \& Helpman, 1993).

Recent literature highlights that economic growth of a country is propelled thru TFP besides conventional factors such as level of private investment, saving rate, labour, and capital productivity (see e.g. Bosworth \& Collins, 2008; Lee \& Hong, 2010; López-Cálix et al, 2012). Manyika et al (2014) explained that disparities in the past and present economic growth and GDP per capita growth of a country is mainly explained by the pool of workers and labour productivity. Felipe (2007) explained that China and India have achieved the high TFP growth in the Asian region through structural transformation, skill development and improving human capital. Collins (2004) estimated average TFP growth; for India 1.19, China 2.68, Bangladesh 0.37, Sri Lanka 0.75 and for Pakistan 0.87 percent during the period of 1960-2003. Jorgenson and $\mathrm{Vu}$ (2005) also estimated the TFP growth for India 2.49, China 2.49, Bangladesh 0.41 and for Pakistan 0.52 during the period of 1995-2003.

However, in Pakistan, economic growth tends to fluctuate with high volatility and decreasing trend relative to 1960 s and 8 os because of political instability, low level of investment, and technically inefficient workforce (Pasha et al, 2002; Khan, 2006; Amjad \& Awais, 2016). It is imperative to examine the structure of real GDP growth while considering the factors other than inputs (labour and capital) to boost the economic growth. Pakistan is lagging behind as compared to its regional competitors in spite of having a greater proportion of youth in its demography and economic potential. The growth of Pakistan is lower than its South Asian counterparts, which needs to be empirically analysed for designing the better policy interventions.

Previously some studies (e.g. see Burney, 1986; Sabir \& Ahmed, 2003; Kemal et al, 2002) have concluded the positive association of economic growth and total factor productivity using growth accounting approach.

Table 1: Productivity Analysis for Pakistan in Literature

\begin{tabular}{|c|c|c|c|c|}
\hline \multirow{4}{*}{$\begin{array}{l}\text { Research Study } \\
\text { Kemal et al (2002) }\end{array}$} & \multirow{4}{*}{$\frac{\text { Period Covered }}{1965-2001}$} & \multirow{4}{*}{$\begin{array}{l}\text { Estimation Methodology } \\
\text { Growth Accounting approach; }\end{array}$} & \multicolumn{2}{|c|}{ TFP growth (percent) } \\
\hline & & & Economy & 1.66 \\
\hline & & & Agriculture & 0.37 \\
\hline & & & Industry & 3.21 \\
\hline Pasha et al (2002) & $1973-98$ & Growth Accounting framework & Economy & 2.2 \\
\hline \multirow{4}{*}{$\begin{array}{l}\text { Sabir and Ahmed } \\
(2003)\end{array}$} & \multirow[t]{4}{*}{$1973-2002$} & \multirow[t]{4}{*}{ TFP Index = output/input } & Economy & 1.8 \\
\hline & & & Agriculture & 2.0 \\
\hline & & & Manufacturing & 4.0 \\
\hline & & & Services & 0.4 \\
\hline World Bank (2006) & 1960-2005 & Growth Accounting Approach & Economy & 1.08 \\
\hline \multirow{4}{*}{$\begin{array}{l}\text { Lopex Calix et al } \\
(2012)\end{array}$} & \multirow[t]{4}{*}{$1981-2011$} & \multirow{4}{*}{$\begin{array}{c}\text { Output per worker/capital } \\
\text { stock, human capital, and } \\
\text { arable land }\end{array}$} & Economy & 1.4 \\
\hline & & & Agriculture & 1.5 \\
\hline & & & Industry & 1.6 \\
\hline & & & Services & 0.9 \\
\hline \multirow[t]{2}{*}{ Park (2010) } & \multirow[t]{2}{*}{$1970-2000$} & \multirow{2}{*}{$\begin{array}{c}\text { Growth Accounting } \\
\text { Approach/with Actual labour } \\
\text { share/constant labour (o.6) }\end{array}$} & $\begin{array}{l}\text { Economy } \\
\text { (actual share) }\end{array}$ & 0.5 \\
\hline & & & $\begin{array}{l}\text { Economy with } \\
\text { labour share } 0.6\end{array}$ & 1.1 \\
\hline
\end{tabular}


Review of Economics and Development Studies, Vol. 7 (2) 2021, 187-203

Source: Author's own compilation

Large variations in the TFP growth in literature are shown in Table 1; which could be due to the use of different time periods, estimation techniques and assumptions in these studies. Park (2010) estimated the lowest TFP growth of 0.5 by using actual labour share and then with assumed labour share of 0.6 and resulted in $1.1 \%$ TFP growth. The overall variation of TFP growth lies from $0.5 \%$ to $1.8 \%$ in these studies. Data analysis and estimation techniques in these studies are based on the oversimplified assumptions because they assumed the coefficient's values and constant return to scale assumption for measuring the share of capital and labour instead of Park (2010) method, who used actual and adjusted labour share while measuring TFP. Therefore, this issue requires a comprehensive empirical analysis of TFP for better evidence-based policy making.

Our study's contribution is three-fold; first, this study employed the data of all the variables on same base year 2005-06, which is never done before in Pakistan's perspective. Therefore, this study may provide more true and recent analysis of real GDP growth and total factor productivity at the aggregated and sectoral level i.e. Agriculture, Industry and Services. Second, this study follows a more robust methodology devised by Cole \& Neumayer (2006), which employs the dynamic return to scale and estimated values of input coefficients instead of constant return to scale and assumed input shares. Third; contrary to the previous studies that rely on traditional growth rate method (e.g Burney, 1986; Martin \& Mitra, 1999; Chaudhary, 2009), we applied the output per worker method e.g. and compared it with growth rate method while estimating TFP.

Rest of the paper is organized as follows; In the following section we explain the data and construction of variables, section 3 illustrates the econometric methodology for TFP estimation, section 4 discusses the results of TFP and growth rates of major variables for the aggregate and sectoral level. The last section presents conclusion and policy recommendation.

\section{Data and Variable Description}

Variables selection and data analysis for total factor productivity is quite a difficult task because TFP estimates are sensitive to the time period coverage, assumptions, and estimation techniques. Some authors use the real GDP growth rates data at constant prices and others use GDP at purchasing power parity (Srinivasan, 2005). We used the data from 1982 to 2016 on a constant base year 2005-06 for all the variables, which are organized as follows:

\subsection{Output}

The data of Gross Domestic Product (GDP) in million rupees is taken from Pakistan Bureau of Statistics at constant factor cost of different years and then it is rebased at 2005-06 (It is the latest available rebasing). Sector-wise data of real GDP is derived from the overall GDP by using the sectoral share of agriculture, industry and services sector. In addition, the sectoral shares are first converted at the same base year 2005-06 before deriving the contribution in real GDP. Because a great deal of structural transformation has occurred during last three decades as agriculture's contribution to GDP has declined to $19.5 \%$ from 30\% in 1980s; Industry's share has increased slightly during these last three decades from $18 \%$ in 1980 s to $21 \%$ in 2016 but showing the sign of premature deindustrialization. While services contribution is continuously increasing from $52 \%$ in 1980 os to $59 \%$ in 2016.

\subsection{Measuring Capital Stock}

We generated the Physical capital stock data series through employing Perpetual Inventory Method and used the Gross Fixed Capital Formation (GFCF) with 5\% depreciation rate to generate the 
capital stock series (see, e.g. Nehru \& Dhareshwar,1993 ; Barro \& Lee, 2010).

Initial Capital Stock

$$
K_{0}=\frac{I_{1 t}}{(g+\delta)}
$$

Where Ko is the initial capital stock and, $I_{1 t}$ is the value of investment at year 1 and delta is the rate of depreciation that is assumed $0.05, \mathrm{~g}$ is the overall GFCF average growth rate.

$$
K_{t}=K_{t-1} *(1-d)+I_{t}
$$

Kt is the capital stock series and $(I)$ is the gross fixed capital formation in million rupees. However, the Capital stock series for each sector (Agriculture, Industry and Services) is generated using sector-wise data of GFCF.

\subsection{Measuring Human Capital}

We used the Barrow-Lee average years of schooling from the World Development Indicators to construct the human capital variable. However, this index is available with five years gap so we interpolated the intermediate values. According to this method, human capital per worker is assumed to have relation with years of schooling that means percentage increase in workers' productivity is due to additional years of education (Barro \& Lee, 2010), which is written as:

$$
h=e^{\varphi(s)}
$$

In this equation $\varphi(s)$ measures the efficiency of per unit of labour with s years of education relative to no education. According to Bosworth \& Collins 2008, the return to an extra year of schooling often fall between 5 to 10 percent; thus, we used the 7 percent assumption which is also in line with López-Cálix et al 2012 and Amjad \& Awais, 2016. The final form of the variable is given below.

$$
H=(1.07)^{s}
$$

\subsection{Measuring the Labour}

Labour is used as the input in the production function and it is measured in different ways as depending upon the availability of data. Mostly it is measured as the number of hours worked. However, working hour's data is not available in Pakistan, therefore, we used the number of workers employed as labour. Data of labour for the overall economy and sector wise is taken as an employed labour force in million from various issues of Labour Force Survey of Pakistan.

\section{Productivity Measurment}

Solow (1957) pioneered the measurement of the TFP; that explains the unrepresented part of the output, which is not captured by inputs. Jorgenson and Griliches (1967) extended this approach using the capital and labour based on production function with constant return to scale. They concluded that TFP measures the intensity and efficiency thru which inputs are utilized in the process of production. Subsequently, literature evaluates the contribution of human capital, which has the potential to enhance TFP through technical and managerial efficiency (see, e.g. Lee and Hong, 2010; Park, 2010; Aiyar and Dalgaard, 2005).

This study follows Cole and Neumayer (2006) and do not restrict $\quad+\quad$ equal to one rather relies 
on actual returns to scale. Besides they included the intercept and error term for measuring TFP, which is the overall unrepresented part of the production function. We used the human capital and physical capital stock for measuring the TFP for the whole economy but for sector level the average years of schooling data is not available. So we used the labour and capital inputs, for sector-wise measurement, which are commonly used and widely accepted. Hence, our TFP estimation technique follows two steps; in the first step we calculated TFP for aggregate level and in the second step we estimated TFP for the sectoral level.

\subsection{TFP Estimation at Aggregate Level}

\subsubsection{Traditional Approach}

Consider the overall Cobb Douglas production function,

$$
Y=A K L
$$

Where as $\mathrm{Y}$ is the real GDP, $\mathrm{A}$ is the total factor productivity, $\mathrm{K}$ is the capital stock and $\mathrm{L}$ is the labour. Whereas $\alpha$ is the elasticity of capital and $\beta$ is the elasticity of labour.

After taking the log and growth rates of the equation (1)

$$
g Y=g K+g L+g T F P
$$

Equation (2) is estimated by applying the OLS method and the residual represents the gTFP given in equation (3)

$$
g T F P=g Y \quad g K+g L
$$

\subsubsection{TFP estimation at Aggregate Level}

The general production function can be represented as:

$$
Y=F(A K H)
$$

We consider the Cobb-Douglas production function

$$
Y=A K H
$$

$\mathrm{Y}$ is the real GDP, $\mathrm{A}$ is the TFP, $\mathrm{K}$ is the capital stock and $\mathrm{H}$ is the human capital; where as $\alpha$ is the elasticity of output with respect to capital and $\beta$ is the output elasticity with respect to human capital.

To break down the above equation (2) to analyse the logarithmic growth rates of inputs in the aggregate output as follow

$$
\ln Y=\ln A+* \ln K+\quad * \ln H
$$

Equation (3) is transformed to output per worker after dividing output and capital with labour. 
It can be written as follow

$$
\Delta \ln y=\varphi_{t}+\alpha * \Delta \ln k+\beta * \Delta \ln H+\varepsilon_{t}
$$

$\varphi_{t}$ in equation (4) is the intercept and $\varepsilon_{t}$ is the error term while $t$ represents the time (years). OLS technique is applied on equation (4) and the coefficients are estimated. While $\alpha+\beta$ is not necessarily equal to one it is allowing the possibility of increasing or decreasing returns to scale.

$$
t f p_{t}=\left(\varphi_{t}+\varepsilon_{t}\right)=\Delta \ln A
$$

\subsubsection{Sector Wise TFP Estimation}

$$
Y=A K L
$$

Equation (1) is divided by labour (L) to transform the equation (1) into per worker form.

$$
\begin{gathered}
\frac{Y}{L}=\frac{A K L}{L} \\
\frac{Y}{L}=\frac{A}{L} \frac{K}{L} \div L L \\
\frac{Y}{L}=A \frac{K}{L} \div L^{+1}
\end{gathered}
$$

After the simplification and taking the log of growth rates we obtain the equation (5)

$$
\ln y=\ln k+(+1) \ln L+\ln A
$$

We estimated the values of coefficients of capital and labour given in equation (6) by applying OLS technique.

$$
\ln y_{t}={ }_{0}+\ln k_{t}+(+1) \ln L_{t}+{ }_{t}
$$

After the estimation of equation (6) we can get the TFP by adding the intercept and error term as given in equation (7).

$$
t f p_{t}=\left({ }_{0}+{ }_{t}\right)=\ln A
$$

\section{Results and Discussion}

\subsection{Analysis at overall economic level}

Table 2 shows the estimates of aggregate production function described by equation (4). These coefficients of physical capital and human capital indicate increasing return to scale at aggregate level of economy. Elasticity of output with respect to human capital is 0.96 , which means that if there is 1 percent change in physical capital there will be 0.96 percent change in the output per worker in the same direction. 
Table 2: Production Estimates at Overall Economic Level -- Ordinary Least Square

\begin{tabular}{|l|c|}
\hline \multicolumn{2}{|c|}{ Dependent Variable Output per worker } \\
\hline Constant & 0.0071 \\
& $(0.005)$ \\
\hline Physical Capital Stock & $0.967^{\star * *}$ \\
& $(0.125)$ \\
\hline Human Capital Adjusted Labour & 0.867 \\
& $(0.714)$ \\
\hline R-square & 0.63 \\
\hline
\end{tabular}

***and ${ }^{* *}$ shows the significance level at $1 \%$ and $5 \%$ respectively

Values in parenthesis are standard error

The output elasticity with respect to human capital $(\mathrm{H})$ is 0.86 , which indicates that if there is 1 percent increases in human capital there will be 0.86 percent increase in the output. The positive sign of human and physical capital illustrates that improving the education of labour and capital in production process may boost the output per worker. Human capital is statistically insignificant because real GDP has numerous determinants and there could be an omitted variable bias. Pakistan's economic performance at aggregate level from 1982 to 2016 is presented in Table 3.

Table 3: Factors of overall economic growth, 1982-2016

\begin{tabular}{|c|c|c|c|c|c|c|}
\hline \multirow[t]{2}{*}{ Period } & \multirow[t]{2}{*}{$\begin{array}{l}\text { Real GDP } \\
\text { Growth }\end{array}$} & \multirow{2}{*}{$\begin{array}{l}\text { Investment } \\
\% \text { of GDP } \\
(2005-06)\end{array}$} & \multirow{2}{*}{$\begin{array}{l}\text { Growth in } \\
\text { Labour } \\
\text { Productivity }\end{array}$} & \multicolumn{3}{|c|}{$\begin{array}{l}\text { Percent Contribution in Labour } \\
\text { Productivity }\end{array}$} \\
\hline & & & & TFP & $\begin{array}{l}\text { Physical } \\
\text { Capital }\end{array}$ & $\begin{array}{l}\text { Human } \\
\text { Capital }\end{array}$ \\
\hline $1982-1990$ & 5.9 & 24.9 & 3.7 & 0.9 & 2.3 & 0.5 \\
\hline 1991-2000 & $4 \cdot 3$ & 22.1 & 2.0 & -0.2 & 1.6 & 0.6 \\
\hline 2001-2010 & 4.4 & 17.7 & 0.7 & 0.7 & -0.7 & 0.7 \\
\hline $2010-2016$ & 3.9 & 13.9 & 2.4 & 1.8 & 0.5 & 0.1 \\
\hline $1982-2016$ & 4.7 & 20.3 & 2.2 & 0.7 & 0.9 & 0.5 \\
\hline
\end{tabular}

Own calculation; rounded off to nearest tenths

Results in Table 3 reflect the declining growth of average real GDP and TFP over the years. Real GDP growth declined to 4.7 percent, from 5.93 percent in 1980 s. It is due to 18 percent decline in investment to GDP ratio as compare to 1980 s besides other factors. The average total factor productivity growth is 0.7 percent, which contributes 15 percent to the average real GDP growth. Average labour productivity growth decelerated to 2.2 percent with contribution of $0.7,0.9$ and 0.5 of TFP, physical capital and human capital respectively. This little contribution from human capital is due to unskilled workforce and lack of quality education in Pakistan. These results corroborates with previous studies. The average TFP growth in previous studies varies from 0.5 percent to 1.7 percent using the different time periods covering from1970 to 2015 i.e. (Lee and Hong; 2010; Chaudhry; 2009; 
Lopez-Calix et.al; 2012 and Amjad and Awais; 2016).

Our results summarize that high real GDP growth in 1980 s was primarily driven by investment on new technology, which in turn raised the TFP, labour productivity and GDP growth. However, in later decades considerable reduction in investment to GDP ratio caused the decline in both TFP as well as labour productivity.

Figure 1 shows the positive association between labour productivity and total factor productivity which means that output per worker increases with efficient resource utilization, improvement in entrepreneurial skills and labour training.

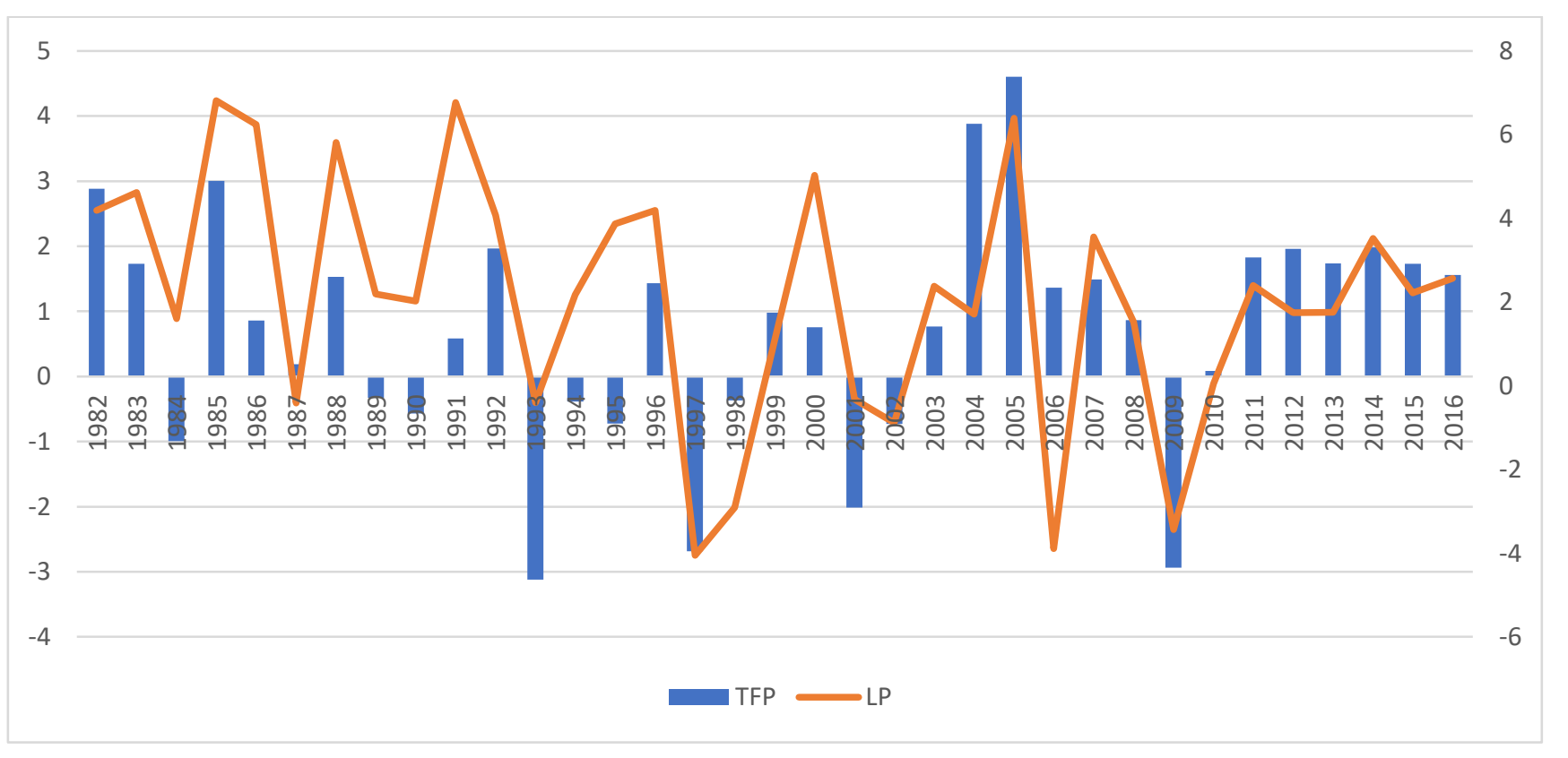

Figure 1: Growth of Labour Productivity and TFP

Vertical bars in the graph represent the TFP and the line presents the labour productivity (LP). In 1982 LP and TFP are 4.2 and 2.9 percent, respectively and it shows the fluctuations throughout the years. The overall labour productivity decreased to 2.6 percent in 2016 from 4.2 percent in 1982 , which is 38 percent less than the LP in 1982. Probably due to a decrease in LP, the TFP declined from 2.9 in 1982 to 1.6 in 2016.

Further, the overall analysis depicts that in the years of political stability both TFP and LP are rising and on the other hand years such as 1991 to 1992, 1997-1998, 2007, 2008, 2009 and 2010 shows the negative trends due to political instability and natural disasters including the floods of 2008 and 2010 in these periods. Similarly, the trends in Figure 2 present the positive relation between real GDP and TFP. 


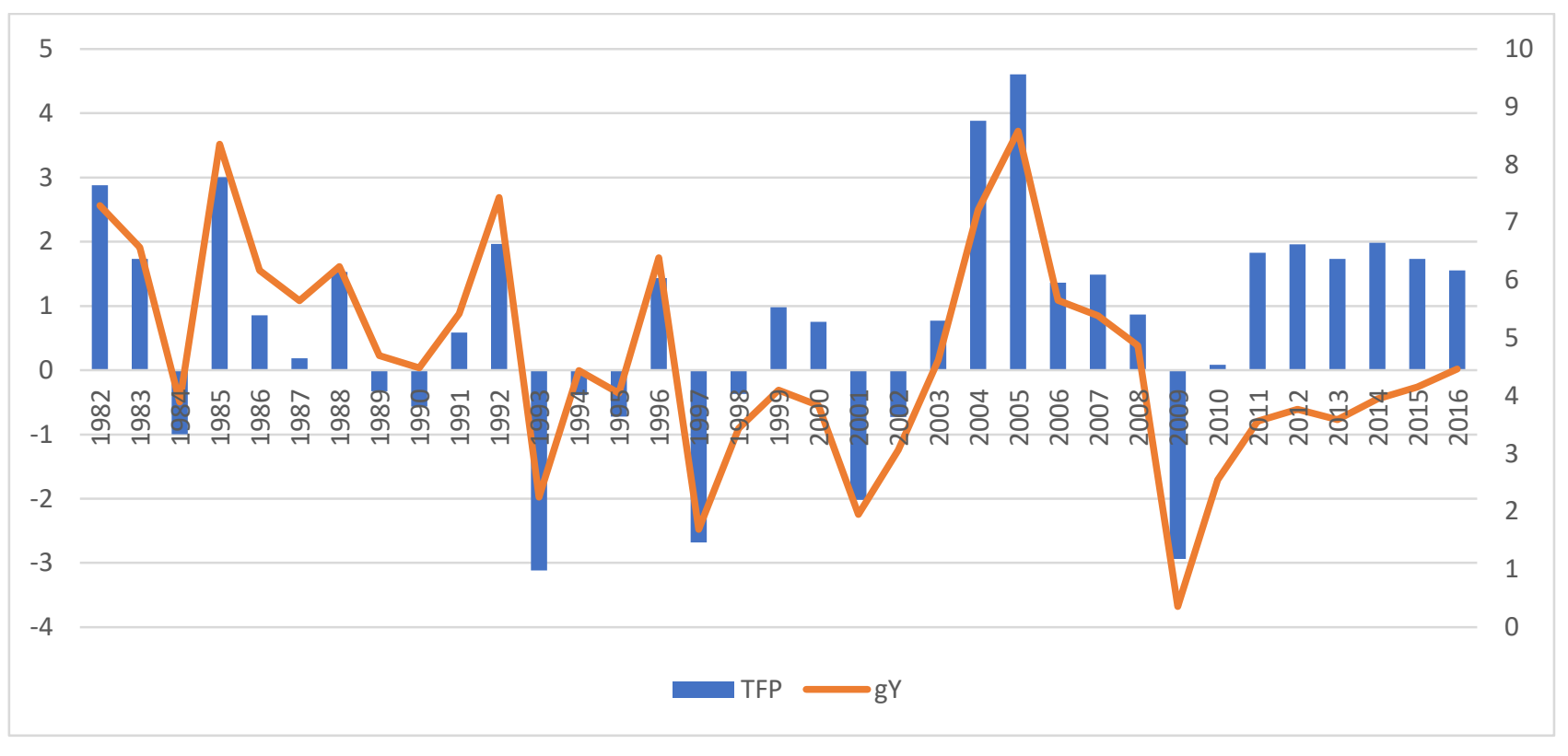

Figure 2: Real GDP Growth and TFP, 1982-2016

Figure 2 shows the average high growth in the 1980s and there are many fluctuations in the 1990 s perhaps due to political uncertainty. Further, then the high growth period started from 2005 and then suddenly declined in 2010 due to intense floods in this year, which caused the damage of infrastructure as well as crops at large in Pakistan. There is positive increase and trend in growth of real GDP and TFP since 2011.

\subsection{Agriculture Sector}

The agriculture sector is considered to be the backbone of Pakistan's economy because $66 \%$ of the population is attached to this sector. It contributes 19.8 percent in GDP and provides jobs to 42.3 percent of the total labour force1. It also plays a vital role in providing raw material to the industrial sector. Therefore, it has forward linkages to the exports and economic development of Pakistan. Total factor productivity has a considerable share in real GDP of agriculture sector. Our study estimated the agriculture TFP through Solow residual applying OLS method by using capital and labour inputs.

Table 4 presents the OLS estimates of production function for agriculture sector by using the capital and labour. The elasticity of output with respect to capital is 0.88 percent that is same through both methods. 
Table 4: Production Function Estimates of Agriculture Sector----OLS result

\begin{tabular}{|l|c|c|}
\hline Coefficients & Output per Worker Method (1) & $\begin{array}{c}\text { Growth Rate Method } \\
(2)\end{array}$ \\
\hline Constant & $\begin{array}{c}0.015^{* * *} \\
(0.005)\end{array}$ & $\begin{array}{c}0.015^{* * *} \\
(0.005)\end{array}$ \\
\hline Capital Stock & $\begin{array}{c}0.88^{* *} \\
(0.37)\end{array}$ & $0.88^{* *}$ \\
& $0.37)$ \\
\hline Labour & $(0.38)$ & $0.12^{* *}$ \\
& 0.64 & $(0.048)$ \\
\hline R-Square & 0.096 \\
\hline
\end{tabular}

$* * *$ and ${ }^{* *}$ shows the significance level at $1 \%$ and $5 \%$ respectively

Values in parenthesis are standard errors

Results are shown in column (1) and (2) are the elasticities of output with respect to inputs. However, we estimated the coefficients or share of inputs by two methods, in column (1) the variables are transformed in output per worker as many previous studies estimated and in column (2) logged form growth rates are taken to estimate the coefficients. The elasticity of physical capital stock is 0.88 that is same in both columns and elasticity of labour varies in two methods although the TFP remain same in each method. Inputs and TFP contribution in real GDP growth of agriculture is presented in Table 5 .

Table 5: Growth in Agriculture Sector and TFP, 1982-2016

\begin{tabular}{|c|c|c|c|c|c|c|}
\hline \multirow[t]{2}{*}{ Period } & \multirow[t]{2}{*}{$\begin{array}{l}\text { Real GDP } \\
\text { Growth }\end{array}$} & \multirow{2}{*}{$\begin{array}{l}\text { Investment } \\
\% \text { of GDP } \\
(2005-06)\end{array}$} & \multirow{2}{*}{$\begin{array}{l}\text { Growth in } \\
\text { Labour } \\
\text { Productivity }\end{array}$} & \multicolumn{3}{|c|}{$\begin{array}{l}\text { Percent Contribution in Labour } \\
\text { Productivity }\end{array}$} \\
\hline & & & & TFP & $\begin{array}{l}\text { Physical } \\
\text { Capital }\end{array}$ & Labour \\
\hline 1982-1990 & 3.9 & 31.9 & 1.8 & 0.6 & 1.2 & -0.0008 \\
\hline 1991-2000 & 4.4 & 21.9 & 2.9 & 2.7 & 0.2 & -0.0006 \\
\hline 2001-2010 & 2.2 & 15 & -0.9 & 1.1 & -2.0 & 0.012 \\
\hline $2010-2016$ & 2.2 & 14.2 & 2.3 & 1.3 & 1.0 & -0.00006 \\
\hline $1982-2016$ & 3.2 & 20.9 & 1.4 & 1.5 & -0.05 & 0.0007 \\
\hline
\end{tabular}

Own Calculation

Table 5 shows the economic performance of agriculture sector. It shows that the average real GDP growth is 3.2 percent with 47 percent contribution from TFP during the period of 1982 to 2016.

Decade wise results reveal that economic performance in199o's is relatively better as real GDP registered 4.4 percent growth with 2.7 percent growth from TFP and 2.9 percent from labour productivity. Agriculture sector boomed in 1990s due to agriculture reforms, trade liberalization policies, subsidized fertilizer and hybrid seeds besides support price programs in this decade. It resulted in high yield of crops and encouraged farmers to enhance cultivation area and production. In 2000 seal GDP growth decreased 50\% from previous decade with sharp decline in investment as well as labour 
Review of Economics and Development Studies, Vol. 7 (2) 2021, 187-203

productivity. It is all due to sensitivity of agriculture sector to weather patterns; series of natural disasters occurred in 2000's; such as earth quack in 2005, floods in 2008 and 2010. Moreover, the average -0.05 percent negative contribution of the physical capital and neglible share of labour in labour productivity indicates the underutilization of capital and uneducated labour attached to this sector. Our estimates of TFP in agriculture sector are reasonably similar to some recent studies i.e. Lopez-Calix et.al (2012) and Amjad and Awais (2016).

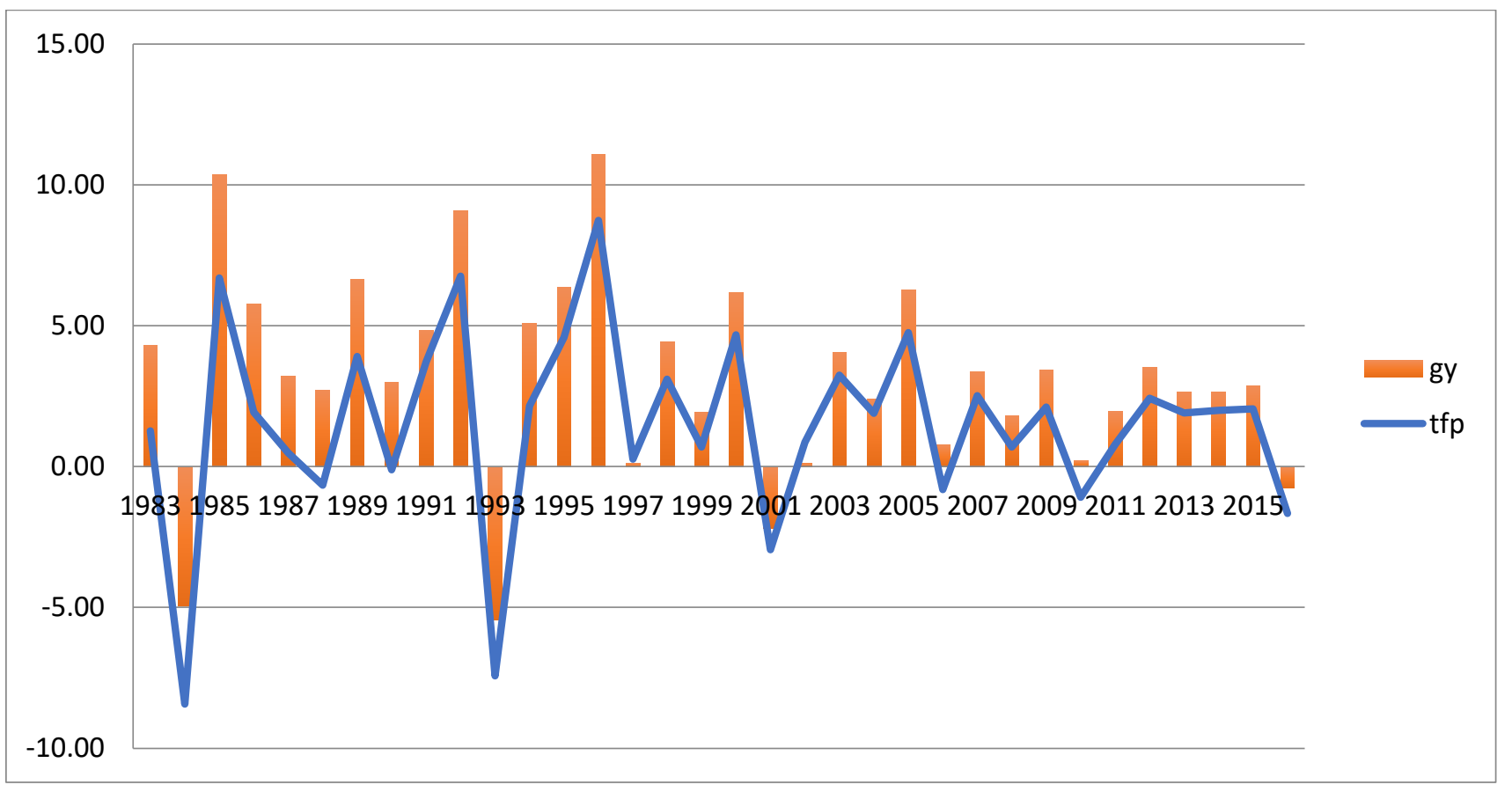

Figure 3: Agricultural real GDP and TFP Growth

Figure 3 shows the trend of real GDP and TFP. Line represents the TFP and vertical bars present the real GDP growth of agriculture sector. It is quite evident that TFP and output growth in agriculture sector move in tandem with each other.

\subsection{Industry}

Industry consists of manufacturing, mining and quarrying. Manufacturing is the second largest sector in the industry, which contributes 13.6 percent to GDP and provides jobs to 15.3 percent of the total labour force. The share of other sectors in GDP such as mining and quarrying, construction, and electricity \& gas distribution are 2.98, 2.58 and 1.85 respectively2. The manufacturing sector is considered to be vital for Pakistan because most of the exports are from textile and semi-manufacturing industries. Strengthening this sector may enhance the export earnings, external competitiveness, and export share in the international market (Ara, 2005).

Our results in Table 6 show that the capital has same elasticity 0.55 in both methods given in column (1) and (2) which represent that if there is one percent change in the capital there will be 0.55 percent change in manufacturing output growth, which is almost similar to Chudhary (2009). 
Table 6: Production Function Estimate for Industrial Sector---OLS results

\begin{tabular}{|l|c|r|}
\hline Coefficients & Output per Worker Method & Growth Rate Method \\
\hline Constant & $0.046^{* * *}$ & $0.046^{* * *}$ \\
& $(0.010)$ & $(0.010)$ \\
\hline Capital Stock & $0.545^{*}$ & $0.545^{* *}$ \\
& $(0.397)$ & $(0.229)$ \\
\hline Labour & $-0.47^{*}$ & -0.015 \\
& $(0.305)$ & $(0.054)$ \\
\hline R-Square & 0.85 & 0.059 \\
\hline
\end{tabular}

$* * *, * *, *$ Show the significance level at $1 \%, 5 \%$ and $10 \%$ respectively

Values in parenthesis are standard errors

The coefficient of capital is also statistically significant at 10 percent significance level. The elasticity of manufacturing output with respect to labour shows negative sign because there is a low level of labour productivity and under utilization of labour in this sector. However, the high growth rate in 1980 s and 2000 s is due to trade liberalization and export-oriented policies, which were favorable for industries.

Table 7: Growth rates of Industrial sector 1982-2016

\begin{tabular}{|l|l|l|l|l|l|l|}
\hline Period & \multirow{2}{*}{$\begin{array}{l}\text { Real GDP } \\
\text { Growth }\end{array}$} & $\begin{array}{l}\text { Investment } \\
\% \text { of GDP } \\
(2005-06)\end{array}$ & $\begin{array}{l}\text { Growth in } \\
\text { Labour } \\
\end{array}$ & & & \multicolumn{3}{|c|}{$\begin{array}{l}\text { Percent } \\
\text { Productivity }\end{array}$} & & TFP & $\begin{array}{l}\text { Physical } \\
\text { Capital }\end{array}$ & Labour \\
\hline $1982-90$ & 7.3 & 46.8 & 5.8 & 6.3 & 0.2 & -0.7 \\
\hline $1991-2000$ & 3.7 & 40.0 & 5.5 & 2.3 & 2.4 & 0.8 \\
\hline $2001-2010$ & 6.5 & 24.7 & -1.2 & 5.8 & -3.4 & -3.6 \\
\hline $2010-2016$ & 3.7 & 10.3 & -1.5 & 4.4 & -3.5 & -2.4 \\
\hline $1982-2016$ & 5.4 & 31.9 & 2.3 & 4.6 & -0.9 & -1.4 \\
\hline
\end{tabular}

Own calculations; Round off to nearest tenths

Results in Table 7 show that Industry grew by 7.3 percent in the 1980 os and 3.7 percent in 1990 . This sharp decline in real GDP growth in 1990s was due to 63 percent decline in TFP, which means that TFP has considerable impact on real GDP growth. Further, results show that negative labour productivity growth in 2000 and 2010 s is -1.2 percent and -1.5 percent respectively. It is perhaps due to sever energy crisis in these periods that worsened in 2010 s and lowered the 50 percent real GDP growth in Industrial sector. It also caused the underutilization of physical capital and labour in this sector, consequently declining the labour productivity and real GDP growth. 
Review of Economics and Development Studies, Vol. 7 (2) 2021, 187-203

Our results of average TFP for Industry is compatible with previous studies and present the true picture of Industrial growth. Sabir and Ahmad (2003) found 4 percent growth of TFP for the period 1973 to 2002. Chaudhry (2009) found the higher TFP growth in Industrial sector than agriculture sector, which is also true in the case of our study. Pasha (2002) found the 6.6 percent TFP growth for small and large-scale manufacturing in 1980 s and this study estimate the 6.3 percent TFP in 1980 .

Real GDP and TFP growth in the industrial sector is depicted in Figure 4. It presents the positive relation between TFP and GDP growth in this sector.

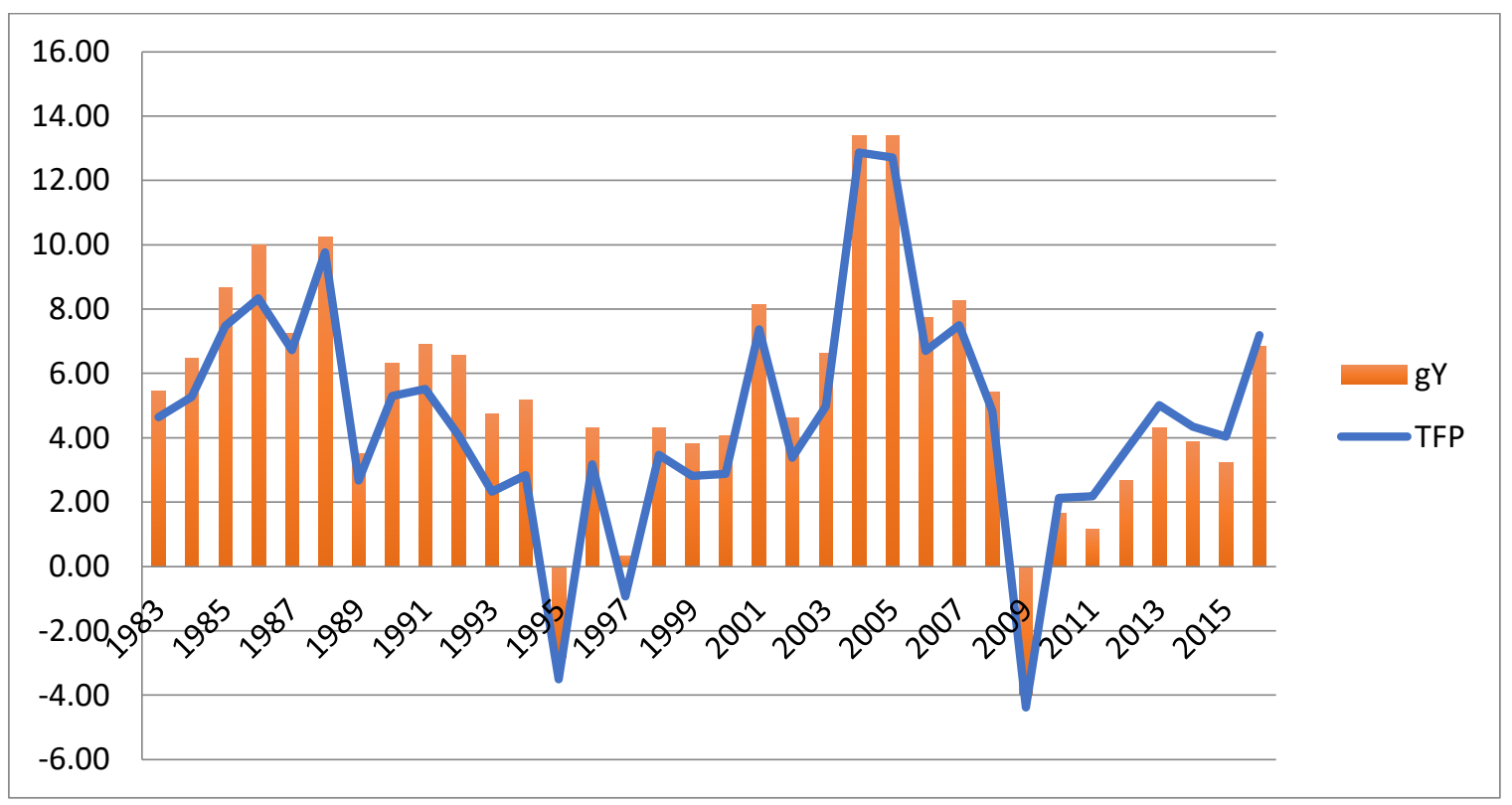

Figure 4: Industrial Sector Real GDP and TFP Growth

The graph shows that industrial sector sustained the average growth of 8 percent from 1980 . Subsequently, it sharply declined to 3.5 percent in 1990's due to political instability, regional uncertainty and lack of implementation of reforms. Further, the negative trend of TFP and GDP occurs in late 2000 due to four natural disasters in five years including the floods of 2008 and 2010 (LopezCalix et.al, 2012).

\subsection{Services Sector}

According to Economic Survey of Pakistan 2015-16, the services sector is growing at more than 6 percent and contributing 59 percent in GDP. Government is trying to exploit its potential by providing a peaceful and conducive environment for economic activity. Despite the high growth of services sector and its high subsector growth, there is lack of research and investment on human capital in this sector.

For the estimation of TFP, we applied the OLS method and results are given in Table 8. Column (1) present the output per worker method's results and column (2) shows the estimates of growth rates method. The elasticity of output with respect to capital is 0.21 , which is similar in two methods. However, elasticity of output with respect to labour is varying in two methods. 
Table 8: Production Function Estimate in Services Sector-----OLS results

\begin{tabular}{|l|c|c|}
\hline Coefficients & Output per Worker Method (1) & $\begin{array}{c}\text { Growth Rate Method } \\
(2)\end{array}$ \\
\hline Constant & $\begin{array}{c}0.041^{* * *} \\
(0.011)\end{array}$ & $\begin{array}{c}0.043^{* * *} \\
(0.014)\end{array}$ \\
\hline Capital Stock & 0.21 & 0.21 \\
& $(0.41)$ & $(0.41)$ \\
\hline Labor & $-0.77^{*}$ & 0.023 \\
& $(0.42)$ & $(0.03)$ \\
\hline R-Square & 0.93 & 0.032 \\
\hline
\end{tabular}

$* * *, * *, *$ Show the significance level at $1 \%, 5 \%$ and $10 \%$ respectively

Values in parenthesis are standard errors

Results interpret that if there is 1 percent change in the capital there will be 0.21 percent change in output of the services sector. Coefficient of labour is negative in output per worker method and positive in growth rate method. However, results are statistically insignificant perhaps due to omitted variable bias. Overall economic performance of services sector is given below in the Table 9.

Table 9: Growth rates in Services sector

\begin{tabular}{|c|c|c|c|c|c|c|}
\hline \multirow[t]{2}{*}{ Period } & \multirow[t]{2}{*}{$\begin{array}{l}\text { Real GDP } \\
\text { Growth }\end{array}$} & \multirow{2}{*}{$\begin{array}{l}\text { Investment } \\
\% \text { of GDP } \\
(2005-06)\end{array}$} & \multirow{2}{*}{$\begin{array}{l}\text { Growth in } \\
\text { Labour } \\
\text { Productivity }\end{array}$} & \multicolumn{3}{|c|}{$\begin{array}{l}\text { Percent Contribution in Labour } \\
\text { Productivity }\end{array}$} \\
\hline & & & & TFP & $\begin{array}{l}\text { Physical } \\
\text { Capital }\end{array}$ & Labour \\
\hline $1982-90$ & 6.3 & 3.4 & 2.8 & 5.2 & 0.23 & -2.6 \\
\hline 1991-2000 & 4.5 & 3.4 & 0.5 & 3.4 & 0.2 & -3.0 \\
\hline 2001-2010 & 5.0 & 3.1 & 3.1 & 4.1 & 0.4 & -1.5 \\
\hline $2010-2016$ & 4.6 & 2.4 & 1.9 & 3.9 & 0.02 & -2.0 \\
\hline $1982-2016$ & 5.1 & 3.2 & 2.0 & $4 \cdot 3$ & 0.2 & -2.4 \\
\hline
\end{tabular}

Own calculation; Round off to nearest tenths

Table 9 shows that 6.3 percent real GDP growth and 5.2 percent TFP growth in 1980 s in services sector. In 1990s low level of TFP and labour productivity growth in this sector cause the decline in real GDP growth. Overall results present that TFP is the crucial driver in services sector's real GDP growth. The fluctuations in real GDP growth are in tandem with TFP and labour productivity. The average labour productivity growth during the period of 1982 to 2016 is 2 percent with 0.2 percent share of physical capital, -2.4 percent contribution of labour and 4.3 percent share of TFP. Overall performance of this sector remained satisfactory over the years but still there is a need to invest in human capital to further exploit the potential of this sector. Figure 5 depicts the picture of stable growth and TFP as compare to agriculture and industrial sector. 


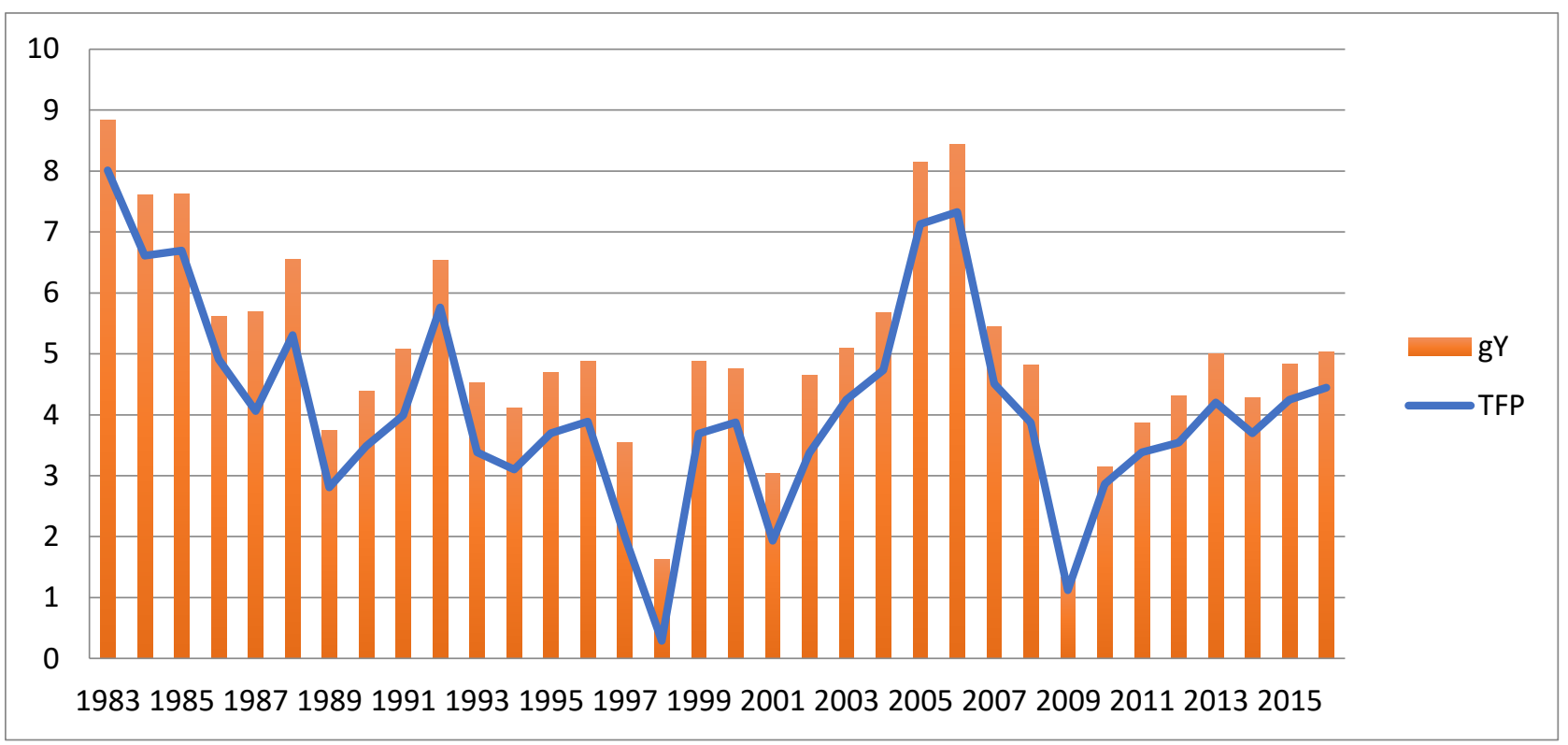

Figure 5: Real GDP and TFP growth in Services Sector

Figure 5 shows that real GDP growth and TFP tandem to each other during the years. However, some fluctuations exist in real GDP and TFP growth such as in the period of 1999 and 2009.

\section{Conclusion}

Long-term economic growth cannot be sustained without high labour productivity, technological advancements and efficient utilization of time and resources. Our results confirm that TFP and real GDP growth are positively correlated at both aggregate and sectoral level in Pakistan's context. The results further confirm that economic growth and the TFP fluctuates in tandem with each other at overall as well as at sector level. During 1982 to 2016, average TFP growth at aggregate level remained 0.7 percent, and sector wise TFP registered a growth of 1.5, 4.6 and 4.3 percent for agriculture, industry and services, respectively. This shows that the TFP growth in Pakistan is quite low as compared to other Asian countries, e.g. TFP growth in China is 4.0 percent, Singapore 2.0 percent, Korea 1.4 percent, Viet Nam 1.5 percent, Thailand 1.5 percent and India 1.4 percent (Lee and Hong 2010). Furthermore, at aggregate level percentage contribution of human capital, physical capital and TFP in economic growth are $11 \%, 19 \%$ and $15 \%$ respectively, which are considerably low as compared to its peer countries.

Our results reveal that real GDP performance varies across sectors; in industrial sector, the highest GDP growth of 7.3 percent in 1980s was driven by high growth in TFP 6.3 percent during the same period. Similarly, the lowest industrial GDP growth in 1990s was also due to a massive decline in TFP during the same period. The services sector also shows the highest 6.3 percent real GDP growth and 5.3 percent TFP growth in 1980s. The sudden decline in services sector GDP growth to 4.5 percent in 1990 s was due to 35 percent decline in TFP from the previous decade. In 1980s services and industrial sector's high real GDP and TFP growth was perhaps due to a high level of investment, trade liberalization, adoption of new technology and economic reforms through deregulation and private sector development.

However, the TFP growth in agriculture sector in all the decades remain considerably low as compared to industrial and services sector. It also caused the relatively low real GDP growth in this 
Review of Economics and Development Studies, Vol. 7 (2) 2021, 187-203

sector. In 1980s TFP growth in agriculture sector was 0.6 percent and the average TFP growth in this sector is 1.5 percent during the period 1982-2016. Furthermore, the physical capital contributes negatively i.e. 0.04 percent in agriculture GDP growth. The reason of negative contribution of physical capital in agriculture sector is due to lack of innovation, underutilization of the existing capital and unskilled and uneducated workforce in this sector. Similarly, the output per worker growth in industry is also negative due to fewer training of workers and lack of market oriented technical education in Pakistan.

Therefore, the situation calls for economic reforms in general and educational reforms, in particular, to give a boost to the productivity in the commodity producing sectors of the economy. Given the demography of the country that $60 \%$ population is below the age of 30 years, if they are imparted quality education and skills then this could enhance the TFP in a quick possible manner. This implies that Pakistan's economy has the potential to follow the high growth trajectory in the short to medium term by merely focusing on the productivity growth.

\section{References}

Amjad, R., \& Awais, N. 2016. Pakistan's Productivity Performance and TFP Trends 1980-2015: Cause for Real Concerns. Munich: MPRA.

Burney, N. A. 1986. Sources of Pakistan's Economic Growth . Pakistan Development Reveiw , 25, 573-589.

Barro, R. J., \& Lee, J. W. 2010. A New Data set of Educational Attainment in the World 1950-2010. New York: National Bureau of Economic Research.

Bosworth, B., \& Collins, S. M. 2008. Accounting for Growth: Comparing China and India. Journal of Economic Perspectives , 22 (1), 45-66.

Chaudhry, A. 2009. Total Factor Productivity Growth in Pakistan: An Analysis of the Agricultural and Manufacturing Sectors. Lahore Journal of Economics , 14, 1-16.

Cole, M. A., \& Neumayer, E. 2006. Impact of Poor Health on Total Factor Productivity . Journal of Development Studies , 42, 918-938.

Collins, S. M. 2004. Economic Growth in South Asia: A growth Accounting Perspective . Washington : World Bank.

Comin, D. 2006. Total Factor Productivity. New York Univesrsity . New York: National Bureau of Economic Research.

Felipe, J. 2007. A Note on Competitiveness and Structural Transformation in Pakistan. Economic and Research Department. Manila: Asian Development Bank.

Grossman, G. M., \& Helpman, E. 1993. Endogenous Innovation in the Theory of Growth . Cambridge: National Bureau of Economic Research .

Jorgenson, D. W., \& Griliches, Z. 1967. The Explanation of Productivity Change. The Review of Economic Studies , 34 (3), 249-283.

Jorgenson, D., \& Vu, K. 2005. Information Technology and the World Economy. Scandinavian Journal of Economics , 107 (4), 631-650.

Kemal, A. R., Din, M.-u., \& Qadir, U. 2002. Export and Economic Growth in South Asia. Islamabad: Pakistan Institute of Development Economics.

Khan, S. U. 2006. Macro Determinants of Total Factor Productivity in Pakistan. State Bank of Pakistan Rsearch Bulletin , 2 (2), 383-401.

Lee, J. W., \& Hong, K. 2010. Economic Growth in Asia: Determinants and Prospects. Economic and Research Department. Manila: Asian Development Bank.

López-Cálix, J. R., Srinivasan, T. G., \& Waheed, M. 2012. What Do We Know about Growth 
Patterns of Pakistan? Washington DC: World Bank.

Nadiri, M. I. 1970. Some Approaches to the Theory and Measurement of Total Factor Productivity: A Survey. American Economic Association , 8 (4), 1137-1177.

Nehru, V., \& Dhareshwar, A. 1993. A New Database on Physical Capital Stock: Source, Methodology and Results. Revista de Analisis Economico , 8, 37-59.

Manyika, J., Remes, J., \& Wotzel, J. 2014. A Productivity Prospective on the Future of Growth . Mckinsey: Mckinsey Quarterly.

Martin, W., \& Mitra, D. 1999. Productivity Growth and Convergencce in Agriculture and Manufacturing . Washington DC: World Bank.

Pasha, H. A., Ghaus-Pasha, A., \& Hyder, K. 2002. The Slowing Down of the Growth of Total Factor Productivity in Pakistan. Karachi: Social Policy and Development Centre.

Prescott, C. E. 1998. A Theory of Total Factor Productivity . International Economic Review , 39 (3), 525-551.

Sabir, M., \& Ahmed, Q. M. 2003. Macroeconomic Reforms and Total Factor Productivity Growth in Pakistan: An Empirical Analysis. Qubec: 56th International Atlantic Economic Conference.

Solow, R. M. 1956. A Contribution to the Theory of Economic Growth . The Quarterly Journal of Economics , 70 (1), 65-94.

Solow, R. M. 1957. Technical Change and the Aggregate Production Function. The Review of Economics and Statistics , 39 (3), 312-320.

Srinivasan, T. N. 2005. Productivity and Economic Growth in South Asia and China . Pakistan Development Review , 44 (4), 479-503.

Romer, P. M. 1990. Endogenous Technological Change. Journal of Political Economy , 98 (5), 71102. 